\title{
Yüzbaşı Mustafa Nazım (Evren) Bey'in Hatıralarında II. İnönü Savaşı ve 5. Kafkas Tümeni ile Dört Gün
}

\author{
Doç. Dr. Serpil SÜRMELİ
}

\section{$\ddot{O ̈ z e t}$}

Aşağıdaki hatıralar, Süvari Yüzbaşı Mustafa Nazım Bey'in, II. İnönü Savaşı sırasında 1. Süvari Tümeni'nin 10. Alayı'na bağlı 3. Bölük Kumandanı olarak 28 Mart-2 Nisan 1921 tarihleri arasinda, 5. Kafkas Tümeni emrinde geçirdiği dört güne ait savaş anılarını kapsamaktadır.

Mustafa Nazım Bey, sade ve akıcı bir dille kaleme aldı̆̆ bu hatıralarını, 5. Kafkas Tümeni Kumandanı Cemil Cahit (Toydemir) Bey'in anısına atfetmişstir. Hatıralar, Batı Cephesi’nin sol kanat grubundaki Inönü-Yörük Yayla mevzilerinde Yunan kuvvetlerine karşı yapılan savaşları ve yenilerek Bursa'ya çekilen düşmanı İnegöl Ovası'nda yakalamak için, Mezit Boğazı-Hamamlı-İnegöl ve Kazancı Bayırı istikametlerinde yapılan takip hareketini konu almaktadır.

Anahtar Kelimeler: II. İnönü Savaşı, 5. Kafkas Tümeni, Mustafa Nazım Evren, Cemil Cahit Toydemir.

\section{Four Days With II Nd. Inonü Battle and 5th. Caucasian Division in The Memories of Captain Mustafa Nazım (Evren) Bey \\ Abstract}

The following memories comprises of the battle memories four days spent by Cavalryman Captain Mustafa Nazim Bey under the command of the 5 th. Caucasian Division between March 28 and April 2, 1921 as the Commander of 3 rd. Squadron under the order of 10 th. Regiment of 1 st. Cavalry Division during II nd. Inonu Battle.

\footnotetext{
Atatürk Üniversitesi Atatürk İlkeleri ve İnk1lâp Tarihi Enstitüsü Öğretim Üyesi 25240/Erzurum.
} 
Mustafa Nazım Bey attributed these memories written out in a plain and fluent language to the memory of Cemil Cahit (Toydemir) Bey, the commander of the 5 th. Caucasian Division. The memories take the battle fought against the Greek army forces in Inonu. Yoruk Yayla locations in the left wing group of West Front, and the follow up movements of the enemy forces withdrawing to Bursa after being defeated in the direction of Mezit Boğazl-Hamamll-Inegol and Kazancl Bayırl in order to seize them in Inegol Plain as the subject matter.

Key Words: II nd. Inonu Battle, 5 th. Caucasian Division, Mustafa Nazım Evren, Cemil Cahit Toydemir.

Aşağıdaki hatıralar, II. İnönü Savaşı sırasında 5. Kafkas Tümeni yanında I. Süvari Tümeni'nin 10. Alayı'na bağlı 3. Bölük Komutanı olarak görev alan Yüzbaşı Mustafa Nazım (Evren)'e aittir.

Mustafa Nazım Bey, 1935 yılında Babalık Gazetesi’nde yayınladığı bu hatıraları o sırada 5. Kafkas Tümeni'ne kumanda eden ve hatıraların yayınlandığı yıl itibariyle Korgeneral rütbesinde bulunan Cemal Cahit Toydemir' in ${ }^{1}$ anısına atfetmiştir.

\footnotetext{
1 Cemil Cahit Toydemir: 1883'de İstanbul'da doğdu. 14 Mart 1900'de girdiği Harp Okulu'ndan 6 Aralık 1902'de teğmen rütbesiyle mezun oldu ve Beyrut'taki 9. Nişancı Taburu 4. Bölüğü'ne, daha sonra Hicaz Şimendüfer Hat Komiserliği'ne tayin edildi. 15 Haziran 1909'da üsteğmen rütbesini atlayarak yüzbaşı rütbesiyle Yemen'deki 49. Alay 3. Tabur 2. Bölük Kumandanlığı'na 1912'de de İstanbul Astsubay Okulu 2. Bölük Kumandanlığı'na atand1. Nisan 1914'te Sivas 3. Numune Tabur Kumandanı oldu. 5 Şubat 1915'te 53. Alay Kumandanlı̆̆ı'na tayin edildi ve 8 Ocak 1915 'de rütbesi Binbaş1lığa yükseltildi. Mart 1916'da 33. Tümen Kumandan Vekili, Temmuz 1916'da Kafkas Cephesi'nde 25. Alay Kumandanı olarak görev aldı. 28 Temmuz 1918 'de yarbaylığa terfi etti. A ğustos 1918 'de 4. Kafkas Tümen Kumandanlığı'na atanmış iken, görülen lüzum üzerine 1. Kafkas Tümen Kumandanlığı'na getirildi. 15 Temmuz 1919'da Samsun'a çıkarak Anadolu'ya geçti ve 5. Kafkas Tümen Kumandanlığı'na atandı. 12 Eylül 1921'de rütbesi albaylığa yükseltildi. 21 Ocak 1922'de 10. Tümen Kumandan1, 18 Ekim 1922'de Tümen Kumandanı yetkisiyle Jandarma 1. Bölge Kumandanı, 31 Ekim 1923'de 41.Tümen Kumandanı olarak görev aldı. 14 Şubat 1926'da 11. Tümen Kumandanlığı'na atandı ve 30 Ağustos 1927'de Tuğgeneral oldu. 18 Ocak 1932'de Milli Savunma Bakanlığı Kara Müsteşarı, 10 Ocak 1933'de 5. Kolordu Kumandanı olarak görev yaptı. 30 Ağustos 1933'de korgeneralliğe yükseltildi. 6 Nisan 1936'da Askeri Yargıtay II. Başkanı, 12 Ocak 1939'da Jandarma Genel Kumandanı, 13 Temmuz 1940'da 20. Kolordu Kumandanı oldu. 30 Ağustos 1942'de orgenerallik rütbesine terfi ederek, Askeri Yargıtay Başkanlı̆̆ı'na atandı. 17 Aralık 1943'te 1. Ordu Kumandanı oldu. 15 Haziran 1946'da da emekliye ayrıldı. 1946-1950 VII.Dönem İstanbul Milletvekili olarak mecliste görev aldı ve aynı dönem bir süre Milli Savunma Bakanlığı yaptı. 15 Temmuz 1956 'da İstanbul'da vefat etti (Birinci Dünya Savaşı'na Katılan Alay ve Daha Üst Kademedeki Komutanların Biyografileri III, Genelkurmay Askeri Tarih Stratejik Etüt Başkanlığı Yayınları, Ankara, 2009, s.273-275).
} 
Mustafa Nazım Evren 1889'da Konya'da doğdu. 11 Nisan 1910'da Harp Okulu'ndan mezun oldu ve Irak'ta bulunan 6. Ordu'ya atand1. 9 May1s 1914'te sicak memleketlerdeki görev süresini tamamlayarak, İstanbul'da 1. Ordu Kumandanlığı'na tayin edildi. 9 Haziran 1914'te 1. Alay 1. Süvari Bölüğ̈̈'ne atandı. 14 Haziran 1915'te terfi ederek üsteğmen oldu. 17 Nisan 1916'da Süvari Depo Alayı'na tayin edildi. Kuzey Kafkas Cephesi'nde Derbent, Petrovski, Demirhan ve Şor savaşlarında bulundu ve 22 Eylül 1917 'de harp madalyası ile taltif edildi. 10 Ekim 1920'de rütbesi yüzbaş̧1lı̆ga yükseltildi. İstiklâl Savaşı'nda 1. Süvari Tümeni 10. Alay 3. Bölük Kumandanı olarak görev yaptı ve bu dönemdeki bütün savaşlara katıldı. 23 Ocak 1922'de Kırmızı Şeritli İstiklâl Madalyası ile ödüllendirildi. 28 Ağustos 1922 günü yapılan taarruzda sağ gözünü kaybetti ve 5. dereceden harp malülü sayıldı. 22 Aralık 1924'te binbaşılığa terfi etti. 23 Şubat 1925 'te 2. Ordu Müfettişliği Süvari Dairesi'nden emekli oldu. 7 Ocak 1941'den, vefat ettiği 20 Nisan 1944'e kadar sırasıyla 5. Kolordu Seyyar Satınalma Komisyonu'nda, Konya Birinci Sinıf İstasyon Kumandanlığı'nda ve Konya Askeri Mıntıka Kumandanlığ 1 7. Şube'de ücret karşılığında görev aldı².

Mustafa Nazım Bey, kumandası altında bulunan 3. Süvari Bölüğ̈̈ ile 5. Kafkas Tümeni'ne katıldığı, II. İnönü Savaşı sırasındaki hatıralarına şöyle başlamaktaydı:

“28 Mart 1921 İkinci İnönü Savaşı’nın geceli gündüzlü süren buhranlı günlerinden biri idi. Alayımızla taraftan tarafa gidiyor, süvarilik vazifelerimizi yapıyoruz. Bugün de alayımız sol taraftan sağ tarafa alınmış cephe gerisinde bir köye yeni gelmiştik. Biraz dinlenip askerlerimiz karavanalarını yemeğe başladıkları zaman bir emireri, alay kumandanının beni çağırdığını söyledi. Hemen yanlarına gittim. Tazim resminden sonra, kumandan beni yanına oturttu. Her ikimizde de beş günden ${ }^{3}$ beri süren uykusuzluk ve yorgunluğun bariz izleri vardı.

"Kumandan:

“-Nazım! Şimdi cepheye 5. Kafkas Tümeni katılmış süvari bölüğü henüz cepheye gelememiştir. Alayımızdan bir bölügün tümene katılması isteniliyor. Senin bölüğünü münasip gördüm. Şimdi bölüğünüzle tümenin bulunduğu Poyra ${ }^{4}$ köyüne hareket ediniz... dedi.

\footnotetext{
${ }^{2}$ Milli Savunma Bakanlığı Arşivi, Askerlik Safahat Belgesi, 326-5 Sicil No'lu Subay Şahsi Dosyas1.

3 Yunan Taarruzu, Güney ve Batı Cephelerine aynı zamanda olmak üzere 23 Mart 1921 sabahı başlamıştı.

${ }^{4}$ Poyra Köyü: Bugün Bilecik İli Bozüyük İlçesi’ne bağlı olup, Eskişehir yolu üzerindedir. Bozüyük'e $15 \mathrm{~km}$, Eskişehir'e ise $30 \mathrm{~km}$ uzaklıktadır.
} 
“-Başüstüne kumandanım! diyerek bölüğe döndüm.

"Savaşın buhranlı ve şiddetli günleri içinde biz zaten gece gündüz harekete hazırdık. Böyle günlerde çizmelerimiz ayağımızdan çıkmaz, eyerler atların sırtından alınmazdı.

"Yemeklerini yiyen askerlerimiz at başına ederek, gece karanlığı basmadan yeni tümeni bulmak için yola çıktık. Gurub zamanı, bir vadinin içine yayılmış olan muntazam yapılı, beyaz badanalı bir köyün içine girdik. $\mathrm{Bu}$ köyde yeni gelmiş bir piyade kıtasının canlı bir kaynaşması vardı. Taze ve dinç ruhlu, muntazam giyinmiş piyade askerleri, bizim ruhumuza da yeni bir tazelik ve dinçlik veriyordu. Köye girdiğimiz zaman karşılaştığımız askerler, bizi güler yüzleriyle selamlayarak, emir almışlar gibi:

"-Ha... siz, bizim tümene gelecek süvariler olacaksınız. Aha şuracıkta han gibi bir yer var. Süvariler oraya yerleşecek dedilerdi, sizi oraya götürelim, diyerek önümüze düştüler.

"Bölüğü tümen kumandanlığının tahsis ettiği bu hana yerleştirdikten sonra, ilk işim tümen kumandanını sormak oldu. Kendilerinin ileriye ateş hattına gittiğini söylediler.

"Ortalık henüz kararmamıştı. Vadinin batısındaki sırtlardan ateş hattına giden beyaz yol, tepelere doğru uzayıp gidiyordu. Atımı dörtnala tepeye sürdüm. Sırtı çıktıktan sonra uzunca süren bir alandan yoluma devam ettim. Keskin 1slıklarla havayı delerek, sağdan soldan geçen fisıltılı makineli tüfek kurşunları ateş hattına yaklaştığımı anlatıyordu. Ortalık alaca karanlığa bürünmüş, düşman tarafinda ufukta gurubun son kızıllıkları kalmıştı. Karşıdan gelen makineli tüfek ateşinin yağmuru içinde biraz daha ilerledikten sonra, yakın bir hedefe top atışı yapan bir topçu bataryamıza rastladım. Bu bataryanın yanında arkası kesilmeyen düşman makineli tüfek ateşinin yağmuru içinde at üstünde malumat alan bir kişi vardı. Bu kişinin kumandan olduğunu anlamıştım. Konuşmayı kesmemek için, bir selâm verip, karşılarında durdum. Bu dakikada topçu subayı vaziyet hakkında malumat veriyor, kumandan vakar ve sükûnetle dinliyor, ben de şu alaca karanlıktan düşman makineli tüfek ateşi altında, atından inmeden yeni geldiği cephe hakkında malumat alan bu kahraman kumandanın ${ }^{5}$ vakar ve sükûnetini resmeden bu tarihi manzaranın unutulmaz anılarını zihnimde not ediyordum.

"Topçu subayı izahatını bitirdikten sonra, kumandanı tekrar selâmladım ve:

${ }^{5}$ Cemil Cahit Toydemir 
“-Tümeniniz emrine verilen süvari bölüğünün kumandanı Nazım!... Bölügümle tümene katıldım dedim.

"Kumandan elimi sıktı ve:

“-Haydi, köye gidelim artık... diyerek atını sürdü. Köye dönüyorduk. Topçu bataryamız mütemadiyen düşmana gülle savuruyor, hakim bir sırtta kurulduğu anlaşılan düşman makineli tüfekleri de, ortalık kararmaya başladığ 1 halde mütemadiyen ateş ediyordu.

"Köye dönerken kumandan bana ilk vazife olarak sabah erkenden bu sırtların bir krokosinin alınmasını, tepelerin ve vadilerin adlandırılmasını söylüyordu. Sabah erkenden teslim olacağımız bu gürültülü cephe hattı karanlıklara gömülerek uzaklaşıyor, biz de köye giriyorduk. Köyde kumandan karargâhına gitti. Ben de bölüğüme geldim.

"Karanlıkta girdiğimiz Poyra Köyü bir muhacir köyü olacaktı. Binaların yapılış tarzı öyle gösteriyordu ${ }^{6}$.

"Bölüğe geldiğim zaman ilk işim, askerimizin yemek meselesini sormak oldu ${ }^{7}$. Bölüğümün subayı Rıdvan bana sevinçli bir yüzle:

“-Yüzbaşım o iş bitti. İyi bir tümene düşmüşüz. Biz gelmeden bir bölüğün karavanasını bile hazırlamışlar. Siz gidince biz de o işi bitirdik. Askerlerimizi uykuya bile yatırdı... dedi.

"Ben bu haberden çok sevinç duydum. Biz de kahvesi olan bu handa birer çay 1smarlayarak, ekmeğimize katık ettik ve yorgun vücutlarımızı dinlendirmeye ve kahve peykesinin ${ }^{8}$ üstünde uyku kestirmeye başladık. Vakit de epeyce geçmişti. Bu sırada karargâhtan gelen bir emir subayı süvari bölüğünün şimdi at başı etmesi ve hareket olunacağı emrini getirdi. Vakit gece yarısını biraz geçmişti. $\mathrm{Bu}$ emir aynı zamanda bütün kıtalara bildirildiğinden, köyde gece karanlığı içinde sessiz bir kaynaşma, bir hareket

\footnotetext{
${ }^{6}$ Poyra Köyü: Osmanlı-Rus Savaşlarında, Rusların Osmanlı tarafında yer alan Kafkas halklarını sürgün ve göçe zorlaması sonucu, 1864'te yurtlarından ayrılan Hatıkoy Çerkeslerinin bir kısmının, 1870-1873 yılları arasında bu köye gelerek yerleşmesiyle kurulmuştur. Onlar Rusya'dan ayrıldıklarında önce Balkanlarda Saracaali/Sarıcaali'ye gelerek burada bir Türk köyünde birkaç yıl kadar kalmışlar, sonra ilk olarak Hatıkoy adıyla kurdukları Poyra'ya gelmişlerdi. 10 yıl sonra Bulgarların Saracali Türklerini göçe zorlamasıyla buradaki Türklerden 50 kadar aile, birlikte yaşadıkları yıllarda iyi komşuluklarından memnun kaldıkları eski komşularının köyüne gelerek yerleşmişlerdi (tr.wikipedia.org/wiki/PoyraBozöyük) Mustafa Nazım Bey’in düşüncesinde yanılmadığ1 Poyra Köyü, görüldüğü üzere sakinleri Cerkes ve Balkan Türklerinden oluşan bir muhacir köyü idi.

${ }^{7}$ Nazım Evren, “2.İnönü Utku'nunda 5. Kafkas Fırkası İle 4 Gün”, Babalık, 8 Nisan 1935, Sayı: 4612.

${ }^{8}$ Peyke: Tahta sedir
} 
başlamıștı. Bölüğü verilen emre göre, köyün güney çıkıșında topladım. Burada tümen karargâhı ile birleşerek, tümen ile İnönü ${ }^{9}$ istikametinde yürüyüşe geçtik.

"Askerler arasında atasözü hükmüne girmiş bir söz vardır. Askerlikte son verilecek emre bak... derler. Biz sabahleyin tutacağımız cephenin gerisine gelmişken, şimdi gece yarısı bu cephenin aksi bir yere gidiyorduk. $\mathrm{Bu}$ da tabii vaziyetin icabi idi.

"Yolumuz vadiler arasından İnönü düzlügüne inerken, ikinci yarıya giren ay da gerimizdeki sırtlardan nurlu ışığıyla yükseliyor, karanlıklara bürünen bu 1 ssız ve sessiz dünyayı aydınlatmaya çalışıyordu. Uzaklarda İnönü’nün koyu gölgeli dağları içinden tek tük parlayan 1şıklar da sönük birer yıldız gibi görünmeye başlamıştı. Sessiz uyuyan bu yarı aydınlık içinde, yarının ödevlerine, savaşlarına girecek olan bu kahraman kafilenin ayak patırtıları gecenin sessizliğini yırtıyor, büyük bir sükûn içinde amacına süzülüp gidiyordu. Geride bıraktığımız sırtlardan müthiş gürültülerle patlayan bombalar, sürekli ve ahenkli makineli tüfek ateşleri, bir gece baskınından dehşet verici ve korkunç çarpışmalarının başladığını bildiriyordu. $\mathrm{Bu}$ müthiş boğuşma gürültüleri, on dakika kadar gecenin sükûnunu bozdu ve sessizlik yine ortalığa hakim oldu.

“Sabah yaklaşırken İnönü’ye girdik... Boz renkli dağlarının eteğine yaslanan İnönü, gündüz savaşlarının yorgunluğunu gidermek için, yarım ay ışığının donuk gölgeleri altında yatağına çekilen heybetli bir aslanın vardığg uykuya dalmış gibiydi. $\mathrm{Bu}$ arada yatağında bütün yağmalara karşı büyük bir ulusun ölmez davasını omuzlarına alan az fakat öz bir ordunun karargâhı oturuyordu. Bu karargâh Türk'ün kara bahtını ak eden ve tarihe "İkinci İnönü Galibi” adıyla geçen General İsmet İnönü’nün karargâhı idi $^{10}$.

"Burada askerlerimizi yerleştirdik. Kumandanla karargâha gittik. Bu odanın mobilyası, iki sandalye, üzerinde haritalarla örtülü bir masa, gözü dolduramayacak kadar 1 şı yanında üzeri kırmızı mavi hatlarla işaret edilmiş olan haritanın üzerinde tetkikler yapan Kurmay Başkanı ${ }^{11}$ oturuyordu. Başını kaldırdığı zaman,

\footnotetext{
9 İnönü, Osmanlı döneminde Anadolu Eyaleti’ne, sonra Hüdavendigâr (Bursa) Vilayeti'ne bağlı bir köydü. Daha sonra merkezi Bilecik olan Ertuğrul Sancağı'nın Söğüt Kazası'na bağlandı. 1923'te il olan Bilecik'in Söğüt İlçesi'nin köyü, 1926'da Bozüyük İlçesi'nin bucak merkezi oldu. 1963'te Eskişehir'in merkez ilçesine bağlanan İnönü, 1987'de de ilçe oldu (tr.wikipedia.org/wiki/İnönü-Eskişehir).

${ }^{10}$ Nazım Evren “2.İnönü Utku'nunda 5. Kafkas Fırkası İle 4 Gün”, Babalık, 10 Nisan 1935, Say1:4613.

${ }^{11}$ Yarbay Naci (Tinaz)
} 
böyle geç vakit ziyarete gelenlerin kim olduğunu birden anladı ve kumandanı yanına oturtarak harita üzerinde tespit edilen son cephe vaziyetini anlatt1.

"General İsmet az evvel yatmıştı. Vazife hakkında görüşüleceği sırada bana izin verildi. Ben karargâhtan çıktım. Vakit çok ilerlemiş, tan ağarmaya başlamıştı. Kasabada biraz sonra kopacak büyük firtınanın yaratacağı heyecanı dinleyen bir sessizlik, havada da sert bir ayaz vardı. Sokaklar gece düşen kırağ ile beyazlanmıştı.

"Erken uyanan kasabalılar kahveye gidiyorlardı. Ben de bunlarla subayların birleştiği kahveye gittim. Arkadaşlarla birer çay içtik.

"Ortalık ağarmaya başlamıştı. Oturduğumuz yerin pencerelerinden İnönü'nün son müdafaa hattı olan tepeler görünüyordu. Bu sırada büyük bir bombardıman gürültüsünden sonra tepelerin üstünde paralanan şarapnellerin beyaz dumanları, tahrip danelerinin kaldırdığı sarı ve siyah toprak sütunları göründü ve yükseldi. 29 Mart sabahının savaşı başlamış bulunuyordu. Sabah erkenden başlayan düşman topçu bombardımanı cephemizin merkezinden sol tarafa doğru yayılıyor, bugün de cephenin merkez ve sol tarafina taarruz edeceği anlaşılıyordu. Üç günden beri cephenin çeşitli noktalarından yaptığ 1 taarruzlarla bir sonuç elde edemeyen düşman, bugün son kozunu oynayacağa benziyordu.

"Cephede bombardıman devam ederken, Cephe Kumandanı İsmet İnönü gözetleme dürbünü ile merkez ve sol taraf vaziyetini gözetleyerek, inceliyor, karargâhın bulunduğu yerden dürbünle hareketi takip etmenin mümkün olduğu anlaş1lıyordu. Bu gözetleme sırasında tümenin toplanması emri verildi. Kasabada canlı bir kaynaşma oldu ve beş dakika içinde tümen İnönü'nün batı tarafındaki caddede toplandı.

"Harekâtın son müdafaa hattı üzerinde görünmesi, vaziyetin çok hat bir devreye geldiğini, cephe kumandanının gözetleme dürbünü başında yeni vaziyetin icaplarına göre acil emirler vermesi, durumun biraz da tehlikeli safhaya girdiğini gösteriyordu ${ }^{12}$.

"29 Mart sabahının güneşi doğarken, bir akşam top, tüfek gürültüleri ve insan boğuşmaları içinde bıraktığı bu yerleri, bugün daha şiddetli ve daha çetin bir savaş içinde bulunuyordu.

"Saat 7.00'ye gelmişti. Biz yol üzerinde savaşa gitme emrini sabırsılıkla bekliyorduk. Cephe Kumandanı, tümen kumandanı

\footnotetext{
${ }^{12}$ Nazım Evren, “2. İnönü Utku'nunda, 5. Kafkas Fırkası İle 4. Gün” Babalık, 14 Nisan 1935, Say1:4615.
} 
karargâhlarıyla geldiler ve beklemekte olan tümeni selâmlayarak teftiş ettiler. Tam zamanında cepheye taze ve muntazam askerin, kumandanlar üzerinde bıraktığı özlü ve güçlü intibalar, yüzlerde ve gözlerde beliren memnuniyet izlerinden anlaşllyyordu. Cephe kumandanı kısa bir teftișten sonra, tümene uğur ve başarı diledi... Tümen yeni aldığı emre göre cephenin sol tarafina Yörük Yayla'ya ${ }^{13}$ doğru harekete geçti.

"Tümen Kumandanı Cemil Cahit Bey ile bizim süvari bölüğü önden hareket etti. Piyadeler bizi takip ediyorlardı. Gece karanlığında katıldığımız tümeni bugün gündüz gözü ile görmüş ve tanımış oluyorduk. Tümenin bir emir subayı ve bir kurmay subayından oluşan karargâhıyla 13. Alay ve bir de iki toptan meydana gelen yarım cebel bataryası cepheye yetişmişti.

"Savaşın en buhranlı gününde cepheye yetişen bu miktarı az fakat esas itibariyle çok değerli olan bu kuvvet cephenin vaziyetini, savaşın talihini değiştirecek bir kudretle vaziyete zamanında müdahale ediyordu.

"Onbeş dakikalık yürüyüşten sonra Yörük Yayla sırtlarının fundalıklı eteklerine geldik. Burada vaziyet şöyle görünüyordu:

"Düşmanın erkenden başladığı bombardıman merkezde devam ediyor, Yörük Yayla'nın karşı sırtlarında dolgun mevcutlu Büyük Millet Meclisi Taburu $^{14}$ Mangal Tepe'ye doğru bir yılan kıvrıntısı ile yürüyor, karşıllklı sırtlar arasındaki İnönü düzlüğüne doğru, uzun bir avcı hattı geri çekiliyordu. Burada rastladığımız bir tümen karargâhından bu çekilen avcı hattının 11. Tümen'e ait olduğunu öğrendik. Tümen kumandanımız burada 11. Tümen Kumandan ${ }^{15}$ ile görüştü. Düşman sol tarafımıza önemli kuvvetlerle bir çevirme hareketi yapmış, Yörük Yayla sırtlarına kadar uzayıp giden bu hareket karşısında 11. Tümen Cephesi'ni geri almaya mecbur olmuştu.

\footnotetext{
${ }^{13}$ Yörük/Yürük Yayla: Eskişehir'in İnönü İlçesi'ne bağl1 köy olup, bugün Eskişehir'e 45 km, İnönü’ye $10 \mathrm{~km}$. uzaklıktadır.

${ }^{14}$ Büyük Millet Meclisi Taburu: Mustafa Kemal Paşa'nın Refakat Subayı İsmail Hakkı (Tekçe) tarafından 18 Temmuz 1920'de 9 manga, 81 er, 3 çavuştan oluşan bir kadro ile kuruldu. Mustafa Kemal Paşa tarafından ilk kez II. İnönü Savaşı sırasında Batı Cephesi emrine girmek üzere görevlendirildi ve 28/29 Mart 1921'de, İsmail Hakkı Bey'in kumandas altında trenle Ankara'dan yola çıkarıldı. Muhafız Taburu 900 tüfek ve 9 makineli tüfekten oluşmaktaydı. (Muhafızı Atatürk'ü Anlatıyor, Emekli General İsmail Hakkı Tekçe'nin Anıları, Yay. Haz: Hasan Pulur, Kaynak Yayınları, İstanbul, 2000, s.18-19, 22; İsmet İnönü, Hatıralar, Yay: Haz: Sabahattin Selek, Bilgi Yayınevi, Ankara, 2006, s.239-240; Sabahattin Selek, Milli Mücadele (Ulusal Kurtuluş Savaşı), II, Örgün Yayınevi, İstanbul, 2002, s.1062).

${ }^{15}$ Albay Mehmed Arif (Ayıc1)
} 
"Kavalca ${ }^{16}$ sırtlarından Yörük Yayla'ya atlayan kuvvetli bir düşman müfrezesi, önümüzdeki zayıf süvari kuvvetlerimizi sürerek, Yörük Yayla'dan İnönü'ye doğru ilerliyor, bu tehlikeli yürüyüş durdurulamazsa, bütün cephemizin sarsılması ve belki bir geri çekilmeye dönüşme tehlikesini gösteriyordu. Burada vaziyet bütün tehlikesiyle apaçık görülüyordu. Bilinmez bir tesirle kendi kendilerine cebri bir yürüyüşe geçmiş olan piyadelerimiz bize yetiştiler. Bir geçit resmi meydanındaki ciddiyet ve intizamla bu alay, vakur bir sessizlikle hedefine doğru yürüyordu ${ }^{17}$. Burada kumandan çevik ve hızlı adımlarla savaş alanına giden tümeni bir daha gözden geçirdi. Yürüyüş kolunun arkasından karargâha ayrılan süvari takımı ile de yürüyüşe geçtik.

"Güneş epeyce yükselmiş, ilkbaharın taze ve yeşil güzelliği ortalığ kaplamıştı. Yaprakları bahar güneşi ile tazelenen fundalıkların ve seyrek ağaçlı ormanın arasından Yörük Yaylası'na doğru ilerliyorduk. Yakın bir mesafeden pek kesik olmayan tüfek ve makineli tüfek sesleri işitiliyordu.

"Yörük Yayla sırtlarının eteğinde iken, sağımızda Kavalca Köyü sirtlarında patlayan bir düşman batarya grup ateşinin şarapnelleri tam tepemizde müthiş tarakalarla patladı. İkinci bir grup da piyadelerimizin üzerlerinde paralandı. Düşman topçusunun bu ateş baskını zayiatsız geçti. Yürüyüş kolu sarsıntısız ve sessiz, durmadan hareket eden çelik bir ray gibi amacına doğru uzayıp gidiyordu.

"Yörük Yayla'nın hakim sırtlarına çıkıyorduk. Atları sırtların gerisinde yedekte görünen bir süvari alayımı,, Yörük Yayla'ya doğru yürüyen düşmanla yaya muharebesi yapıyordu. $\mathrm{Bu}$ alay, sabah erkenden taarruza geçen düşmanı, bu dakikaya ve bu mevzilere kadar müdafaa ederek çekilmiş, 5. Kafkas Tümeni'nin vaziyete tam zamanında ve yerinde müdahale etmesi için icap eden vakti kazandırmıştı.

"İleride görülen sırtların tepelerinde karlı parçalar görünüyor, bu karlı tepeler üzerinde yayılan mat renkli avcı hatlarımız beliriyordu. Kavalca sırtlarında gizlenmiş bir mevziden ateş eden düşman topçusunun gönderdiği şarapneller, nazlı tepelerin ve avcı hatlarının üstlerinde beyaz şemsiyeler gibi küme küme açılıp paralanıyordu. Avcı hattı dalgalanmadan ve irkilmeden seri adımlarla ilerliyor, sırtları tutuyor, sabahtan beri zayıf süvari kuvvetlerimizi sürerek ilerleyen kuvvetli düşmanla, 5. Kafkas Tümeni'nin kahraman 10. Piyade Alayı, ilk çarpışmaya giriyordu.

16 Kavalca/Kovalca/Kovalıca Köyü, bugün Bilecik İli’nin Bozüyük İlçesi’ne bağlı olup, Bilecik'e 41 km, Bozüyük'e 7 km uzaklıktadır.

17 Nazım Evren, “2.İönü Utku'nunda 5. Kafkas Fırkası İle 4 Gün”, Babalık, 15 Nisan 1935, Say1:4616. 
"Bu dakikada süvarilerimiz (14. Süvari Alayı) geniş ve emniyetli bir nefesle, savaş meydanını piyadelere bırakarak, avcıları atlarının başlarına geliyor, kısa bir piyade savaşından sonra tüfek sesleri kesiliyor ve tümen kumandanının emriyle mevzii alan topçumuz, düşman topçusuna mukabele ediyordu.

"Taze piyade kuvvetleriyle karşılaşan düşmanın ileri yürüyüşü, tümenin ilk hamlesi ile durdurulmuş, karşı sırtlarda kendine müdafaa mevzii almaya mecbur edilmişti ${ }^{18}$. Bu kısa fakat güçlü hamle ile tümen, düşmanın ileri yürüyüşünü durdurmuş, ilerleyen avc1 hatlarını geri sürmüş ve düşmanı hücum vaziyetinden müdafaa vaziyetine geçirmişti.

"Kumandan vaziyeti tetkik etti. Düşman ileri yürüyüşü durdurulmuş, ilerisi için müdafaa ve taarruza elverişli hakim mevziler elde edilmiş olduğundan, şimdilik tutulan mevzilerin derhal tahkim edilmesi, düşman taarruzuna şiddetle ve icap ederse karşılıklı taarruzlarla karşı konulması emrini verdiler. Biz, tümen kumandanı ve karargâhıyla avcı hattının gerisinde İnönü düzlüklerine karşı, sırtlara nazır ve topçu bataryasının yanında bulunuyorduk. Burada tümenin aldığı vaziyet hakkında Cephe Kumandanlığı'na rapor gönderildi.

"Tümen kumandanı cebinden çıkardığı bir kağıda bulunduğumuz yerlerin mükemmel bir krokisini çizerek vaziyeti bunun üzerinde tespit etti. Tümen kumandanının bu derece mükemmel bir krokici olduğunu hiç düşünmemiştim. Bu vazifeyi bana verseydiler, bu kadar kısa bir zamanda böyle mükemmel bir kroki yapmayı süvari subayı olduğum halde, beceremeyeceğime kanaat getirdim.

"Sabahtan beri buhranlı hadiselerin geçtiği bu tarafta, öğleden sonra saat 3.00’te vaziyet şu şekilde tespit edilmişti:

"11. Tümenimizi ve karşısındaki süvarilerimizi çekilmeye mecbur eden ve Kavalca sırtlarından, Yörük Yayla'ya kadar takriben 6 km'lik bir saha üzerinde, sol tarafımıza karşı yaptığı bir çevirme hareketi ile İnönü'ye onbeş dakikalık bir yürüyüş mesafesi kalan düşmanın çevirme hareketi, 5. Kafkas Tümeni'nin mukabil taarruzlarıyla durdurulmuş, Kavalca Köyü, kuzeybatıdan ilerleyen diğer bir düşman kolu, Büyük Millet Meclisi Taburu'nun yaptığı ve 1. Süvari Tümeni'nin koruduğu şiddetli ve kanlı bir taarruzla durdurulmuş, 11. Piyade Tümeni geri çekilmesini durdurarak, tümenimizin sağından, İnönü düzlükleri üzerinde genel cephenin sol tarafla 5. Kafkas Tümeni arasında bir koltuk teşkil eder şekilde mevzii almış ve

18 Nazım Evren, “2.İnönü Utku’nunda 5. Kafkas Fırkası İle 4 Gün”, Babalık, 22 Nisan 1935, Sayı: 4620. 
İbrahim Bey'in kumandasındaki süvari kuvvetleri de 5. Tümen'in sol tarafını korumak üzere, bu cepheye katılmıştı.

"Bu dakikada ordumuz için pek büyük tehlikeler gösteren düşmanın sol tarafımıza yaptığı taarruzlar tamamen durdurulmuş, İkinci İnönü Savaşı’nın makus talihi değiştirilmişti.

"Bu tarafta teşekkül eden yeni vaziyetin genel kumandası 5. Kafkas Tümeni Kumandanı Cemil Cahit Bey'e verilmişti. Epeyce uzun bir cephe teşkil eden bu sahada, tümen kumandanı, kumandasındaki kıtalara devamlı emirler gönderiyor, Tümen Emir subayı Sait $\mathrm{Bey}^{19}$, bölüğümün subay ve askerleri bu emirleri vaktinde yerlerine götürmek için avcı hatları arasında mekik dokuyorlardi ${ }^{20}$.

"Artık bütün cephede sükûnet vardı. Büyük savaşlar, kanlı maceralarla geçen 29 Mart gününün akşamı yaklaşıyordu. Gurup zamanı Tümen Kumandanı Emir Subayı Sait'i, topçu bataryası kumandanını ve beni yanına aldı. Cephemizin sağ ve sol tarafina hakim avcı hatlarımızın bulunduğu sırta gittik. Burada geceyi geçirmek ve 30 Mart sabahı yapılacak harekât için, lazım gelen emirleri vermek ve arazi üzerinde bu harekâtı görüşmek üzere tümen emrinde bulunan kıta kumandanlarını yanına çağırdı.

"Güneş batıyor, düşmanın işgâl ettiği 500 metre ilerimizdeki sırtlarda hiçbir düşman izi ve hareketi görülmüyordu. Ufka resmi düşen bu tepe üzerinde kıta kumandanları tamamıla toplanmış, kumandanın emirlerini bekliyorlard1. Bulunduğumuz yerler, toprakla karışık sert kayalıklardı. Düşmandan hiçbir eser görülmeyen karşı sırtlardan bir bataryanın grup ateşi ve tepemizde paralanan dört şarapnelin gürültüleri, düşman topçu mevzinin karşımızda ve 1000 metre kadar yakınımızda olduğunu gösterdi. Arkasından gelen ikinci gülle yağmuru, bizi tepelerin gerisine çekilmeye mecbur etti. Mesafe yakın olduğundan düşman topçusu tam isabetle güllelerini savurmuş, bir arada patlayan şarapnel danelerinin parçaları şiddetli bir dolu sağanağ 1 gibi kayalıklar üzerinde şakırdayarak zıplamış, etrafımız şarapnel

\footnotetext{
19 Mustafa Nazım Bey, Sait Bey ile ilgili hatıratında aşağıdaki bilgiyi dipnot olarak vermektedir: Savaş Arkadaşım Sait Bey'in halen Devlet Demiryolları 6. İşletme Müfettişi bulunduğunu kendilerinden aldığım mektuptan anladım ve çok sevindim. Sayın Arkadaşımın mektubu ise, şudur: Savaş Kardeşimiz Sayın Bay Nazım Evren, bugün önümde toplanmış mahalli gazeteleri okurken, sıra Konya gazetelerine geldi ve ikinci yaprağında, çok mühim anların hatıralarıyla çalıştığım "5.Kafkas Fırkası İle 4 Gün” başlı̆ğ gözüme ilişti. İşte şimdi, o yazdığınız yazılar tamamen önümde canlandı ve beni çok duygulandırdı. İşte ben, Poyra Köyü'nde uyuduğunuz kahve peykesi üzerinde sizi uyandıran tümen emir subayıyım. Hürmet ve sevgi ile gözlerinizden öperim savaş kardeşim.

${ }^{20}$ Nazım Evren, “2.İnönü Utku'nunda 5. Kafkas Fırkası İle 4 Gün”, Babalık, 24 Nisan 1935, Say1: 4621.
} 
danelerinin siyah yuvarlaklarıyla dolmuştu. Ben bunlardan birkaçını hatıra olmak üzere cebime yerleştirdim. Tepenin gerisine çekildikten ve birkaç grup da, tepelerin gerisine savurduktan sonra topçu ateşini kesti. Ortalık alaca karanlığa bürünüyordu.

“Tümen kumandanının emriyle, ben bölüğümün başına gittim. Burada kumandan, yarınki harekât için icap eden emirleri verdikten sonra karargâhıyla geldi. Geceyi geçirmek üzere beraber Yörük Yayla Köyü'ne gittik. Bölüğün ağırlığı burada idi.

"Bugünkü harekât sırasında yemek, içmek namına hiçbir şey aklımıza gelmemiş, bir şey de yememiştik. Oturduğumuz köy odasında ağırlıkta bulunan arkadaşların hazırladıkları bulgur pilavını iştahla yedik ve çizmeler ayağımızda portatif olarak yattık. 48 saatten beri uyku yapmamıştık. Cephedeki sükûndan istifade ederek, bu gece biraz uyuyabilecektik. Sabahleyin erkenden kalk1lacaktı. Cephenin solunda bulunan 10. Alay'in 3. Taburu, karşısındaki düşman mevzilerine bir taarruz yapacaktı.

"Sabah gün doğmadan cepheye hareket ettik. Cephenin solunda büyük makineli tüfeklerimizin katıldığı yoğun bir piyade ateşi ile savaş başlamışt1 ${ }^{21}$.

“30 Mart sabahı başlayan bu savaş, düşmana çok ağır zayiata mal olmuştu. Esasen taarruza hazırlanmış olan taburun cephesine, düşman aynı cepheden daha önce taarruza geçmiş, ani bir baskın yapmak umuduyla ilerleyen düşmanın avc1 hatları, yoğun piyade ve makineli tüfek ateşlerimizin tesiri altında erimişti. Bu suretle taburun vazifesi kolaylaşmış, ani ateş baskını ile sarsılan düşmanın taarruzu imha edildikten sonra, mukabil taarruzla düșman geriye atılmıș, bu taburun da tutması elzem olan mevziler işgâl edilmişti. Bu sabah savaşından sonra, düşman artık bu tarafta hiçbir harekete geçememiş, sağ ve sol tarafta bulunan 1. ve 2. Süvari Tugayları, keşif taarruzlarıyla düşmanı hırpalamış durmuşlardı.

"Bugün genel cephenin merkez ve sol tarafinda düşman taarruzundan, bombardımanından hiçbir eser görünmüyor, yalnız sağ taraftan derinden top sesleri işitiliyordu. Düşmandaki bu durgunluğun sebeplerini anlamak için, kumandan süvarilere mütemadiyen keşif yaptırıyordu ve bu keşif hareketleri de mevzii çarpışmaları icap ettiriyordu.

"İşte 30 Mart gününün savaşı, bizim cephemizde böyle geçmişti. Düşmanın 29 Mart’taki hareketlerine karşı, bugün hemen bütün cephede

${ }^{21}$ Nazım Evren, “2.İnönü Utku’nunda 5. Kafkas Fırkası İle 4 Gün”, Babalık, 25 Nisan 1935, Sayı: 4622. 
genel bir hareketsizliği ve manalı bir sükûtu vardı. Birgün önce azgın bir saldırışla çok şeyler yapmak istediğini anlatan düşman, bugün hareketsiz ve durgun yerinde kalmıştı. Acaba yarın yapacağı yeni taarruzlar için taze kuvvetler mi bekliyor, bir dinlenme mi yapıyordu?

"Cephedeki durgunluk, 30 Mart akşamına kadar zihinleri böyle düşüncelerle işgâl etmiş, günün aydınlığ 1 da hiç sır vermeden yerini karanlıklara bırakmıştı. Gecenin karanlığı basınca, düşman işgâlindeki Bozüyük'ten $^{22}$ yükselen yangın alevleri bu esrarlı durgunluğun sebeplerini aydınlatır gibi oldu. Kumandanın emri ile gece karanlığında düşman mevzilerine doğru yaptırılan keşif yoklamalarının hiçbir ateşle karşılanmaması, inanılmaz bir muamma gibi düşmanın geri çekildiği kuşkularını kuvvetlendirmişti. Gece yarısına doğru kumandanımız Cemil Cahit Bey, büyük bir sevinç ve neşe içinde düşmanın geri çekildiği hakkındaki kanaatini açıklamış, karargâhı zafer neşeleri doldurmuştu.

"Bir tesadüf eseriyle karargâhın bulunduğu köyden geçen telgraf hattının açık bulunması, sevinç veren bu zafer haberinin ilk olarak kumandanımız tarafından Eskişehir ve Ankara'ya bildirilmesini mümkün kılmıştı. Bu haberin karargâha yayılması, yorgun dimağları dinlendirmiş, gözlerden uykuyu silmişti.

"Bu saatte bizim karargâha katılan Albay Refet (Bele) Bey'in karargâhı ile kalabalıklaşan köyde, neşe artmış, telefonla civar cephelerdeki kumandan ve subaylar arasında, zafer tebrikleri alınıp verilmeye başlanmıştı. Zaferin doğuşunu gündüz gözü ile görmek isteyen gözler, bu gece hiç uykuya kapanmadan sabahı beklemişti ${ }^{23}$.

“31 Mart sabahı güneş, parlak ışığını etrafina zafer neşeleriyle saçarken, 5. Kafkas Tümeni'nin muzaffer 10. Alayı'nın kahraman Mehmetçikleri işgâl ettikleri tepelerde serbest bir kaynaşma içinde takip hazırlıkları yapıyor, karşılarındaki düşmanın gece karanlığında çekilip gittiğini anlıyorlardı.

"31 Mart sabahı düşmanın boşalttığı cephede, takip harekâtı başlıyordu. Saat 8.00'de, iki karargâhla 12 saat önce düşman işgâlinde bulunan tepelere doğru hareket ettik. Bu tepelerde bırakılmış yığın yığın cephane sandıkları, kazma, kürek, tüfekler, çelik şapkalar, düşmanın gece karanlığında pek acele geri çekilme hareketine geçtiğini anlatıyordu.

${ }^{22}$ Bozüyük, Bilecik İli’ne bağlı ilçe olup, doğuda İnönü, batıda İnegöl İlçelerine komşudur.

${ }^{23}$ Nazım Evren, “2.İnönü Utku'nunda 5. Kafkas Fırkası İle 4 Gün”, Babalık, 2 Mayıs 1935, Say1: 4626. 
“Üç süvari tümeni ile, 5. Kafkas Piyade Tümeni Albay Refet Bey'in kumandasında İnegöl ${ }^{24}$ üzerinden, Bursa'ya çekilen düşmanı takip etmek ve İnegöl Ovası'nda yakalamak üzere takibe koyuldu.

"İnönü-Bursa şosesi üzerinden çekilen düşmanın iki piyade tümenine paralel bir yürüyüşle Mezit Boğazı'na ${ }^{25}$ doğru yürüdük. Cephemizde düşman gece çekildiğinden, vuruşmadan yürüyüşe devam ediyorduk. Yürüdüğümüz dağlı ve ormanlı tepelerin arasında birkaç yerde attıkları kurşunların boş kovanları yanında, bu kanlı savaşın ve şerefli zaferin yolunu açan şehitlerimize rastladık. Çoğu milli kıyafetleri ile savaşa girişen bu yiğitler, nurlu yüzleriyle, ebedi uykularına dalmışlardı. Biraz ileride rastladığımız köylülere kumandan, bu şehitlerin görülmesini tembih etti.

"31 Mart gecesini, sakinleri tarafından boşaltılmış bir köyde geçirdik. 1 Nisan sabahı Mezit Boğazı'na girdik ve gece karanlığına kadar, boğazda yürüyerek Mezit Köyü'nde gece birkaç saat mola verdik. Mezit Boğazı'nın yüksek ve gürbüz çam ormanlarıyla örtülen tepeleri müstesna bir servet ve güzelliğin örnekleri idi.

"Gece yarısından sonra, süvariler ileride olmak üzere hareket ettik. 1 Nisan sabahı saat 9.00'da, İnegöl Ovası'na hakim olan Hamaml1 ${ }^{26}$ sırtlarına geldik. Süvarilerimiz bizden önce ovaya inmişler, cebri bir yürüyüşle İnegöl'den, Bursa'nın Kazancı Bayırı ${ }^{27}$ müstahkem mevzilerine doğru çekilen düşman piyade tümenlerini takibe koyulmuşlar ve temasa geçmişlerdi. Süvarilerimiz düşmanı yakalamak ve İnegöl Ovası'nda hırpalamak için tam zamanında ovaya inmişlerdi. Bizse biraz geç kalmıştık. 5. Kafkas Tümeni Hamamlı sırtlarını işgâl ederek, süvarilerimizin harekâtının sonucunu beklemek vaziyetini almıştı.

“İnegöl şosesinde dörtnala ilerleyen 1. Süvari Tümeni’nin 10. Alayı (Bölüğümüzün mensup olduğu alaydı) İnegöl'ün doğu çıkışında düşmana yetişti. Düşman artçılarıyla savaşa girişti ve İnegöl'ü yakmasına meydan vermeden düşmanı oradan attı. Alayımız İnegöl'de bir sokak çarpışması yaptığından, İnegöl'ün batısında mevkii alan düşman bataryaları, İnegöl'ü bombardıman ettiler. $\mathrm{Bu}$ dakikada düşmanın bütün kısmı Kazanc1

24 İnegöl, Bursa'ya bağlı ilçe olup, şehir merkezine $45 \mathrm{~km}$. uzaklıktadır.

25 Mezit Boğazı: İnegöl-Bozüyük arasında bir vadi olup aynı ismi taşıyan bir dere ve köy bulunmaktadır. 1858'de Rus zulmü sebebiyle Anadolu'ya kaçarak gelen Abhazların kurduğu Mezit köyü, bugün İnegöl İlçesi’ne bağlıdır. Bursa'ya 74 km, İnegöl'e ise 29 km uzaklıktadır.

26 Hamamlı: Bursa İli’nin İnegöl İlçesi'ne bağlı köy. Bursa'ya 57 km, İnegöl'e 12 km uzakliktadir.

27 Kazancı Bayırı: Eski Bursa-İnegöl yolu üzerindeki mevkii ve aynı ismi taşıyan köy. Kazancı, şimdiki adıyla Şükraniye olan köy, Bursa’nın Kestel İlçesi’ne bağlı olup, Bursa'ya 29 km., İnegöl'e ise 16 km. uzaklıktadır. 
Bayırlarına doğru seri bir yürüyüşe çekiliyor. Bizim süvari tümenleri de, ateş menzili dışında düşmana paralel bir gidişle, Kazancı Bayırı'na doğru ilerliyordu.

"Manzara pek heyecanlı idi. Biz büyük bir sabırsızlık ve heyecan içinde süvarilerimizin hücumunu bekliyorduk. Burada süvarilerimiz ya kanlı fakat şerefli bir atlı hücumunu göze aldırarak düşmanı dağıtacak yahut yaya savaşıyla düşmanı önleyerek, Kazancı Bayırı'ndaki müstahkem mevzilere girmesine mani olacaklardı. Düşman durdurulunca, 5. Kafkas Tümeni de seri bir yürüyüşle vuruşarak, bu avı yakalamak mümkün olacaktı. Fakat her ne sebeptense beklediğimiz işler olmadı. Süvarilerimizin takibinin bir yan yürüyüşü yapmasından ibaret kalması, düşmanın Kazancı mevkilerini işgâl etmesine meydan verdi. Bugünün savaşı da bu sonuçla tamamlandı.

“Geceyi Hamamlı Köyü’nde zafer neşeleri içinde geçirdik.

"2 Nisan sabahı dört gün geceli gündüzlü şanlı ve şerefli savaş arkadaşlı̆̆ını yaptığımız kahraman 5. Kafkas Tümeni'nden ayrılarak, alayımıza katılıyor ve Uludağ'ın karlı bellerinden aşarak, Afyonkarahisar Cephesi’ne doğru ilerliyorduk...,28

Mustafa Nazım Bey'in yukarıdaki hatıraları Güney Cephesi ve Ankara'dan Batı Cephesi'ni takviye etmek için, 10. Kafkas Alayı ve Meclis Muhafiz Taburu'nun 5. Kafkas Tümeni Kumandanı Yarbay Cemil Cahit Bey kumandasında, cephe ihtiyatını teşkil etmek üzere İnönü'ye indirilmesi ${ }^{29}$ ve kumandanı bulunduğu 3. Süvari Bölüğü ile, Poyra Köyü'nde bu tümene katılmasıyla başlayan dört günlük anıları kapsamaktadır.

Mustafa Nazım Bey, bir süvari subayı olarak görev aldığ1 II. İnönü Savaşı'nın bir kesitini, kendisinde iz bırakan anıları ve andıklarıyla kaleme alırken, kuşkusuz hafızasında resmettiği bu tarihi atmosferi paylaşmak suretiyle geleceğe aktarmak istemiş, bu vesileyle kendi kaleminden o günleri yeniden yadetme firsatı ve kendisini de tanıtma imkânı sağlamıştır.

\footnotetext{
28 Nazım Evren, “2.İnönü Utku'nunda 5. Kafkas Fırkası İle 4 Gün”, Babalık, 6 Mayıs 1935, Say1:4628.

${ }_{29}$ Türk İstiklal Harbi, II, Batı Cephesi, 3. Kısım, Birinci, İkinci İnönü, Aslıhanlar ve Dumlupınar Muharebeleri (9 Kasım 1920-15 Nisan 1921), Genelkurmay Basımevi, Ankara, 1999, s.388.
} 


\section{BİBLIYYOGRAFYA}

\section{Milli Savunma Bakanlığı Arşivi}

Birinci Dünya Savaşı’na Katılan Alay ve Daha Üst Kademedeki Komutanların Biyografileri, III, Genelkurmay Askeri Tarih Stratejik Etüt Başkanlığı Yayınları, Ankara, 2009.

İnönü, İsmet, Hatıralar, Yay Haz: Sabahattin Selek, Bilgi Yayınevi, Ankara, 2006.

Muhafızı Atatürk'ü Anlatıyor, Emekli General İsmail Hakkı Tekçe’nin Anıları, Yay Haz: Hasan Pulur, Kaynak Yayınları, İstanbul, 2000.

Selek, Sabahattin, Milli Mücadele (Ulusal Kurtuluş Savaşı), II, Örgün Yayınevi, İstanbul, $2002^{3}$.

Türk İstiklal Harbi, II, Batı Cephesi, 3.Kısım, Birinci, İkinci İnönü, Aslıhanlar ve Dumlupınar Muharebeleri (9 Kasım 1920-15 Nisan 1921), Genelkurmay Basımevi, Ankara, $1999^{3}$

\section{Babalık}

tr.wikipedia.org/wiki/İnönü-Eskişehir

tr.wikipedia.org/wiki/Poyra-Bozüyük 